\title{
The Development of Intelligence Test Media for Children with Hearing Impairment
}

\author{
Ana Rafikayati*, Sambira \\ Special Education Department \\ Universitas PGRI Adi Buana \\ Surabaya, Indonesia \\ *ana@unipasby.ac.id, sambira@unipasby.ac.id
}

\author{
Mudhar \\ Guidance and Department Department \\ Universitas PGRI Adi Buana \\ Surabaya, Indonesia \\ mudhar@unipasby.ac.id
}

\begin{abstract}
Children with hearing impairment known to have an average IQ below average. After further analysis the results are obtained because the tests given are verbal test. Whereas for children with hearing impairment, they have difficulty in understanding verbal language. Therefore, it is necessary to develop intelligence tests media adjusted to their characteristics. The aim of this study was to describe the intelligence test media as product developed and to describe the feasibility of product developed. This research used Research and Development research $(R \& D)$ that consisting of 5 stages start from research and information gathering to main product revision. The research subjects in this study were 2 psychologists, 2 media experts (design), 2 teachers of children with hearing impairment, and 6 students of SDLB-B Karya Mulia Surabaya consisting of grade 1-6 elementary school. The primary data collection technique in this study was through questionnaire and observation. The data analysis technique used quantitative data analysis techniques. Then data were evaluated according to the feasibility criteria of the rating with the score of 0.00-5.00 (not feasible-very feasible). The result of this research was intelligence test media for children with hearing impairment that are visualized into sign language and animation videos. Based on the results of the content expert, media, readability and field test, the result was 3,538 (feasible), 4 (very feasible), 3,945 (feasible), and 3,869 (feasible). Based on the results it can be concluded that the intelligence test media for children with hearing impairment is feasible.
\end{abstract}

Keywords-intelligence test media, children with hearing impairment

\section{INTRODUCTION}

Intelligence is the embodiment of a power in humans that affects a person's ability in various fields. Intelligence plays a role in storing and binding back an information, constructing concepts, capturing relationships and making conclusions, processing materials and composing a combination of materials [1].

It was known that the IQ of children with hearing impairment was at the level of mental retardation. The same thing was found when they conducted a study again in 1924, the IQ of children with hearing impairment was below the hearing children. This research reported based on the results of the investigation of research on IQ tests of children with hearing impairment in 1930-1967 obtained data that most of the results showed similar results which was the IQ of children with hearing impairment under hearing children, especially for profound hearing loss children [2]

Although there have been many research results stating that the intelligence of children with hearing impairment is below average, it should be re-analyzed about the measuring instruments used in measuring the IQ of children with hearing impairment. There were many biased studies of psychologists, the habit of measuring the IQ of children with hearing impairment consisted of bias in the test method, sample of research subjects, and lack of experience of the tester [2]

The intelligence characteristics of children with hearing impairment generally have the same distribution of IQ scores as hearing children [3]. Even if there are difficulties that arise, are more associated with talking, reading and writing but these rights are not related to the level of intelligence. In general, intelligence of children with hearing impairment is no different from other children. So, like other children, there are those who have an above-average intelligence level, average and underaverage [4].

For now, intelligence tests that are often used are still verbal intelligence tools. So that when children with hearing impairment is tested for intelligence, the results are below average. This happens not because their intelligence is low, but because the measuring instruments used cannot measure their intellectuality precisely because of language development disorders experienced by children with hearing impairment due to hearing loss. To measure intelligence of children with hearing impairment appropriately, test instrument should be made in the form of performance tests, such as form board test, picture completion, block design and other forms that are more visual. In addition, the tester should also be a person who is 
experienced in interacting with them, so that deviations from test results do not occur [5].

In the case of nonverbal intellectuals, children with hearing impairment and hearing children have the same ability [6]. Children with hearing impairment who master the language get better language ability scores than children with hearing impairment who do not master the language on all measures of performance and verbal IQ [7]. This can be interpreted that some considerations need to be taken in the use of intelligence testing equipment. This is very important so that the child can be given an intervention quickly and precisely. The late identification of children with hearing impairment and delayed early intervention services had an impact on the low communication skills and language [8].

Due to hearing impairment, children with hearing impairment have difficulties in communicating verbally, both expressively (speaking) and receptive (understanding the speech of others) [9]. This situation causes children with hearing impairment to experience obstacles in communicating with other people. On verbal intelligence tests, children with hearing impairment are less able to demonstrate their abilities because of the developmental language disorders. The results of intelligence tests for children with hearing impairment are low not because children cannot answer questions but because children do not understand the instructions given.

Based on the phenomena, it is known that inaccuracies often occur in measuring intelligence on children with hearing impairment. This is because the existing test equipment does not measure children's intelligence appropriately because of the nature of verbal testing instruments while children with hearing impairment experience interference with language development and verbal communication. Therefore, it is necessary to develop intelligence tests media that are adapted to the characteristics of children with hearing impairment.

The Wechsler Intelligence Scale for Children (WISC) intelligence test is one of the most frequent and commonly used tests in psychology. The WISC test is the intelligence test most often used by psychologists. Based on interviews with 30 psychologists at the Indonesian Psychology Association in East Java on January 16, 2016 regarding intelligence tests used, 13 stated that they often used WISC, 11 Binet Simon and 6 people used other test instruments.

The WISC intelligence test is an intelligence test for children aged 8-15 years. This test consists of 2 types of tests, namely verbal tests and performance tests. Verbal tests consist of information material, understanding, calculation, equation, vocabulary, range of numbers. While the performance test consists of completing images, arranging images, designing blocks, assembling objects, symbols, and mazes [1]. In implementing the WISC test for children with hearing impairment, many experts use modifications and adaptations. Some experts choose to only use performance tests and some are still using both (verbal and performance) with some modifications such as adding images. Even so, there are no specific rules that are patented so that the test model that is most suitable for children with hearing impairment is unknown.

Based on this explanation, the need for intelligence test media for children with hearing impairment has not been fulfilled. This study aim to develop the intelligence test media for children with hearing impairment. With intelligence test media that are appropriate to the characteristics of children, it is expected that the IQ of children with hearing impairment can be measured precisely that are appropriate to the characteristics of children so that educational services can be provided in accordance with the potential possessed and they can develop optimally. The purpose of this study was to (1) to describe the intelligence test media as product developed and (2) to describe the feasibility of product developed.

\section{METHODS}

This research used Research and Development research ( $\mathrm{R}$ \& D) by Borg and Gall's that consisting of 5 stages start from research and information gathering to main product revision [10]. Below is the description of the stages of R \& D that have been held in this research.

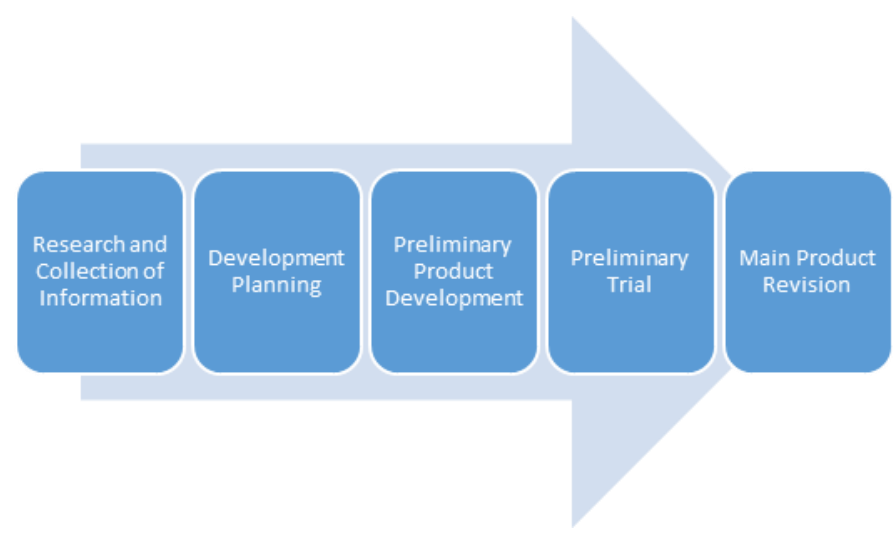

Fig. 1. Research stage

This research took place at Laboratorium of Media Production Universitas PGRI Adi Buana and at SDLB-B Karya Mulia Surabaya II. The research subjects in this study were 2 psychologists, 2 media experts (design), 2 teachers of children with hearing impairment, and 6 students of SDLB-B Karya Mulia Surabaya (elementary special school) in Surabaya consisting of grade 1 to grade 6 . To define field test this study used cluster sampling technique. This location was chosen because SDLB-B Karya Mulia Surabaya II is also a school that uses the Indonesian Language Sign System (SIBI) in teaching and learning process. In addition, SDLB-B Karya Mulia Surabaya is the biggest special school for children with hearing impairment in East Java so that the number of research subjects can be fulfilled. The primary data collection technique in this study was through questionnaire to psychologist and teachers, and observation to students during test. The data analysis technique used quantitative data analysis techniques. Then the data was evaluated which are very feasible for score 4.0-5.00, 
feasible for score 3.0-3.99, enough feasible for score 2.0-2.99, less feasible for score 1.0-1.99, and not feasible for score $0.0-0.99$.

\section{RESUlTS AND DISCUSSION}

\section{A. Results}

The result of this study is an intelligence test media for children with hearing impairments. The description of intelligence test media for children with hearing impairment can be seen in Figure 1 and 2 as follows.

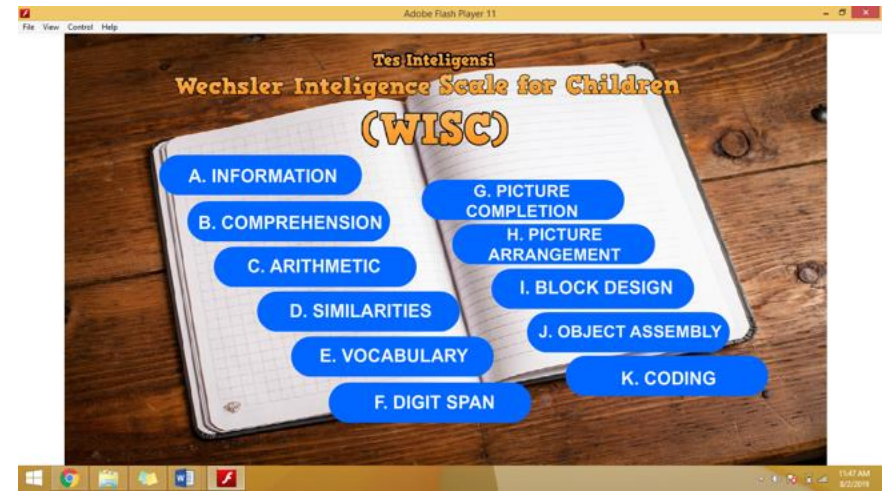

Fig. 2. The display of front page menu of the media.

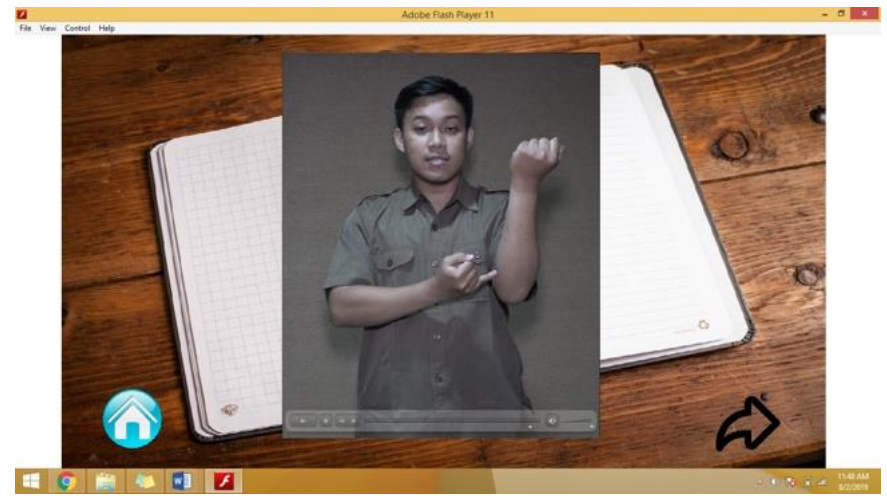

Fig. 3. The display of instructions (questions) in sign language.

Development of intelligence test media for children with hearing impairment adapted the WISC intelligence test. The adaptations made are as follows.

- Changed some instructions in the test instrument because the language used is too complex and difficult to understand for children with hearing impairment

- Eliminated some of the instructions that children with hearing impairment does not understand

- Changed verbal instructions into sign language visualized through video

- Changed the hard file media to soft file in the form of animation
- Presented test instrument in one application (software)

- This intelligence test application is equipped with a guide book on the use of applications for psychologists. This usage guide book is produced in print in the form of a book with A5. This guidebook is produced in print because printed books are more comfortable to read. Beside that A5 size was chosen to aim of practicality. With a small size, this guidebook can be carried everywhere because it does not take up space and is enough to put in a bag.

- The WISC intelligence test instrument for children with hearing impairment consists of 10 parts. In its development, the ten sections were developed and adapted according to the characteristics of children with hearing impairment. This is consistent with Mc Kay (2010) which states that a good evaluation tool is one that can be well understood by students so that they can avoid misperceptions of answers.

- Considering that the product is designed to be used by psychologist, the sign language used is accompanied by sound and subtitles. This is done to facilitate users in using this product.

- In addition, instructions and parts per aspects are explained in detail to avoid misinterpretation. A sentence is said to be effective if (1) appropriately represents the author's ideas, (2) able to generate the same ideas in the reader's mind as thought's writer [11].

Feasibility results were obtained from expert validation. Validation of this product were from 2 psychologists, 2 media experts (design), 2 teachers of children with hearing impairment, and 6 students of SDLB-B Karya Mulia Surabaya (elementary special school) in Surabaya consisting of grade 1 to grade 6 . Based on the results of the content expert, the result was 3,538 (Feasible). Based on the results of the media expert, the result was 4 (Very Feasible). Based on the results of the readability, the result was 3,945 (Feasible). And finally the result from field test was 3,869 (Feasible).

\section{B. Discussion}

Based on the results of the content expert, media, readability and field test, the result was 3,538 (Feasible), 4 (Very Feasible), 3,945 (Feasible), and 3,869 (Feasible). Based on the results it can be concluded that the intelligence test media for children with hearing impairment is feasible.

Based on content expert result it can be conclude that the content of intelligence test media for children with hearing impairment is suitable based on psychology content which is WISC test. The Wechsler Intelligence Scale for Children (WISC) intelligence test is a test that is often and commonly used in the world of psychology. The WISC test is the intelligence test most often used by psychologists. The WISC intelligence test is an intelligence test for children aged 8-15 years. This test consists of 2 types of tests, namely verbal tests and performance tests. The verbal test consists of information 
material, understanding, calculation, equations, vocabulary, number ranges. While the performance test consists of completing pictures, arranging images, designing blocks, assembling objects, symbols, and mazes [1].

The WISC test has the ability to describe various aspects of children's intelligence, such as insight and interest in knowledge, short-term concentration and memory, various abilities such as: language, mathematics, logical and abstract thinking, visual motoric coordination, visual perception organization, visual-spatial relationship and field dependence, adaptation to the environment and understanding of social norms (related to social problem anticipation and social skills), and creativity. Several studies have used WISC to reveal clinical symptoms in children, such as main brain dysfunction / brain damage, emotional disturbance, anxiety, delinquency, learning disabilities and others [12]

Based on content expert result it can be conclude also that the content of intelligence test media is suitable and also suitable with the characteristic of children with hearing impairment.

Due to the poverty of language poverty experienced as a result of hearing loss, children with hearing loss cannot optimize their intelligence. Therefore, only a few of them can show their achievements. In general, children with hearing loss have an average low education and only a few can go on to higher education (university).

The low achievement of children with hearing loss does not come from intellectual barriers but because achievement requires good language skills. Due to their lack of language skills, limited information and lack of abstraction power, they are left behind in general achievement. For now, there are no children with hearing loss who have a Doctorate degree in Indonesia and only a few who feel that college is a non-verbal subject, such as fine arts, fashion design, graphic design, and other non-verbal majors.

Based on that, media for children with hearing impairment should be use easy word. Wagino [9] state that due to hearing loss, children with hearing impairment have difficulty communicating verbally, both expressively (speaking) and receptively (understanding other people's speech). This situation causes children with hearing impairment to experience obstacles in communicating with other people's environments. On the verbal intelligence test, children with hearing impairment are less able to show their abilities due to language development disorders they experience.

Beside use easy word, Intelligence testing for children with hearing impairment should use brief instructions. This is due to language development disorders experienced by children with hearing impairment. So that it has an impact on children's listening, speaking, reading and writing skills. With shorter instructions, it is hoped that children can more easily understand the commands given by the tester.

In addition, media can use sign language. Due to the language barrier experienced by children with hearing impairment, they use a different approach to communication with children in general, this is due to hearing loss, they also experience problems in speaking. One of the communication approaches used is sign language. Sign language is the language used by them in communicating. In its use, each country has its own sign language according to the agreements and culture of each country. In Indonesia, the commonly used sign language is the Indonesian Sign Language System (SIBI).

Considering that the communication approach that is often used by children is through signs, the test tool that should be used to measure children's intelligence should use language that children understand. One of them is use sign language. With the adaptation of changing instructions from verbal to visual, it is hoped that children can understand the instructions given so that children can answer instructions better according to their abilities.

The last but not least, test for children with hearing impairment must use demonstrations. Demonstration is a test process by means of practice using demonstrations. In children with hearing impairment who experience problems in verbal language. Intelligence tests should be adapted to tests that are practical or demonstration. This is in accordance with the opinion of Affendi [5] which states that to measure the intelligence of them children appropriately, test kits should be made in the form of performance tests, for example board test forms, picture completion, block designs and other forms that are more visual in nature. In addition, the tester should also be someone who has experience in interacting with them, so that any deviation in test results does not occur.

Based on media expert and field test result it can be concluding that intelligence test media is easy to use and suitable with the characteristic of children with hearing impairment. Instructions of test shown in a visual form (which can be helped by pictures and videos). Children with hearing impairment understand things more than what they see, not what they hear. Because of that, children with hearing impairment are often referred to as "visual human". With such conditions, they need more time in the learning process, especially for verbalized subjects [4].

The performance of children with hearing impairment is often lower than that of normal children because it is influenced by the ability of children with hearing impairment to understand verbalized lessons. However, for lessons that were not verbalized, children with hearing impairment developed as fast as normal children. Intelligence aspects that come from verbal are often low, but aspects of intelligence that are based on vision and motor skills will develop rapidly [5]

\section{CONCLUSION}

- The product development results, intelligence test applications for children with hearing impairment that visualize into sign language and animation videos.

- Based on the results of the content expert, media, readability and field test, the result was 3,538 
(Feasible), 4 (Very Feasible), 3,945 (Feasible), and 3,869 (Feasible). Based on the results it can be concluded that the intelligence test media for children with hearing impairment is feasible.

\section{REFERENCES}

[1] Nur'aeni, Tes Psikologi: Tes Intelegensi dan Tes Bakat. Yogyakarta: Pustaka Pelajar, 2012.

[2] M. Vernon, "Fifty years of research on the in telligence of deaf and hard-of-hearing children: A review of literature and discussion of implications," Journal of Deaf Studies and Deaf Education. 2005, doi: 10.1093/deafed/eni024.

[3] R. M. Gargiulo, Speial Education in Contemporary Society: An Introduction to Exceptionality 4th ed. California: Sage Publication. Inc., 2012.

[4] H. T. S. Somantri, Psikologi anak luar biasa. 2007.

[5] M. Affendi, "Pengantar Psikopedagogik Anak Berkelainan," Mycol. Res., 2006.
[6] J. P. Braden, "The structure of nonverbal intelligence in deaf and hearing subjects.," Am. Ann. Deaf, 1985, doi: 10.1353/aad.0.0135.

[7] M. D. Remine, "The relationship between spoken language ability and intelligence test performance of deaf children and adolescents," J. Deaf Educ., 2009.

[8] P. Kushalnagar, K. Krull, J. Hannay, P. Mehta, S. Caudle, and J. Oghalai, "Intelligence, parental depression, and behavior adaptability in deaf children being considered for cochlear implantation," 2007, doi: 10.1093/deafed/enm006.

[9] Wagino, "Pelaksanaan Auditory Verbal Therapy (AVT) dalam mengembangkan keterampilan berbahasa anak tunarungu," J. Pendidik. Luar Biasa UNESA, vol. 9, no. 1, 2013.

[10] M. D. Borg, W. R., \& Gall, Educational research. an introduction (5th ed.). White Plains: NY: Longman., 1989.

[11] G. Keraf, Sebuah Pengantar Kemahiran Berbahasa. Ende Flores: Nusa Indah, 1984.

[12] Nanik, "Penelusuran Karakteristik Hasil Tes Inteligensi WISC Pada Anak Dengan Gangguan Pemusatan Perhatian dan Hiperaktivitas,” J. Psikol., 2000. 